\title{
Mercury Bioaccumulation in Eggs of Hens Experimentally Intoxicated with Methylmercury Chloride and Detoxified with a Humic-Aluminosilicate Preparation
} http://dx.doi.org/10.1590/1516-635x1704531-536

-Author(s)

\author{
Barej $R^{\prime}$ \\ Dobrzański Z \\ Popiela-Pleban $\mathrm{E}^{\prime}$ \\ Bubel F" \\ Polak-Juszczak L"II
}

Department of Environment, Animal Hygiene and Welfare, Wroclaw University of Environmental and Life Sciences, Chełmońskiego 38C, 51-630 Wroclaw, Poland

" Poltegor-Institute, Institute of Opencast Mining, Parkowa 25, 51-616 Wroclaw, Poland

III National Marine Fisheries Research Institute, Kołłątaja 1, 81-332 Gdynia, Poland

\section{Mail Address}

Corresponding author e-mail address Zbigniew Dobrzański

Wroclaw University of Environmental and Life Sciences, Wroclaw, Poland.

Phone: +48 713205866

E-mail: zbigniew.dobrzanski@up.wroc.pl

\section{neywords}

Eggs; humic-aluminosilicate preparation mercury.

\begin{abstract}
The aim of the study was to evaluate the effectiveness of preventivedetox preparation (P-dP) based on humic and aluminosilicate substances in the diet of laying hens ( $3 \%$ daily dose) previously intoxicated with methylmercury chloride $\left(\mathrm{CH}_{3} \mathrm{ClHg}, 5 \mathrm{mg} \mathrm{Hg} / \mathrm{kg}\right.$ feed mixture) for six weeks. Mercury content in the whole eggs of the group intoxicated with $\mathrm{CH}_{3} \mathrm{ClHg}$ increased compared to the control group: 488-fold after 1 wk, 622 -fold after 2 wks, and 853-fold after 6 wks of intoxication. The use of $\mathrm{P}-\mathrm{dP}$ in the group previously intoxicated with $\mathrm{CH}_{3} \mathrm{ClHg}$ reduced he mercury content of whole eggs by $18.4 \%$, on average, whereas the average was $29.9 \%$ two weeks after the discontinuation of $\mathrm{CH}_{3} \mathrm{ClHg}$ and P-dP supply. Maximum Hg content in the whole egg was observed in group III (299.7 g), whereas the highest mercury level was obtained in the egg albumen.
\end{abstract}

\section{INTRODUCTION}

Mercury ( $\mathrm{Hg}$ ) and its compounds are commonly present in both biotic and abiotic environment. Mercury is not needed for the life processes of plants, animals and humans, and it is considered an environmental poison, especially in its organic forms. It demonstrates potent chemical and biological activity, which causes enzyme function disorders and changes in DNA phosphoric bonds that are connected with its genotoxic and cytotoxic effect (Barygina et al., 2010). Mercury poisoning causes numerous metabolic disorders and diseases in humans, including neurological, immunological and cardiovascular problems (Zahir et al., 2005; Virtanen et al., 2007). Currently, mercury poisoning in humans or animals is observed very rarely. However, $\mathrm{Hg}$ application in various technological processes and considerable emissions from natural sources and industrial plants represents a potential hazard due to its excessive accumulation in the environment and food chain (Chojnacka et al., 2005; Clarkson \& Magos, 2006; Bykowski \& Dobrzański, 2014). Extensive poultry production systems are especially vulnerable to $\mathrm{Hg}$ uptake from the environment. High concentrations of this metal in muscles, liver, kidneys, and eggs have been detected, especially in industrialized regions (Dobrzańskiet al.,2003; Van Overmeire et al., 2006; Barej et al.,2009), posing a potential threat to consumers' health. It should also be mentioned that poultry embryos are particularly sensitive to methylmercury; therefore, reducing methylmercury levels transferred to the egg may be beneficial for embryos development. There are some methods limiting mercury accumulation in the body of livestock, such as the dietary addition of selenium compounds or special aluminosilicate and humic compounds; however, their efficiency is not fully determined in poultry (Marettova et al., 2003; Żarski et al., 2003; Lukashenko \& Khamidullin, 2005). 
Barej R, Dobrzański Z, Popiela-Pleban E, Bubel F, Polak-Juszczak L
Mercury Bioaccumulation in Eggs of Hens Experimentally Intoxicated with Methylmercury Chloride and Detoxified with a Humic-Aluminosilicate Preparation
The aim of the study was to evaluate an effect of the inclusion of a preventive-detox humic-aluminosilicate preparation $(\mathrm{P}-\mathrm{dP})$ in the feed of laying hens previously intoxicated with methylmercury.

\section{MATERIAL AND METHODS}

A total of 48 Tetra SL laying hens at the age of 52 weeks were used for the study. The hens were housed in 16 cages and distributed into four dietary treatments ( $A, B, C$ and D) with three replicates of 12 hens each. The experiment was conducted in an environmentally controlled room with lighting regimen of $16 \mathrm{~h}$ light: $8 \mathrm{~h}$ dark. Feed and water were provided ad libitum during the entire experimental period. Both control and treatment diets were formulated to be isocaloric (11.6 $\mathrm{MJ} / \mathrm{kg}$ ) and isonitrogenous (16.1\% crude protein). The control group (A) was fed with standard feed mixture (SFM) without any additives; group B was given SFM with $3 \%$ addition of the preventive-detox preparation $(\mathrm{P}-\mathrm{dP})$; group $\mathrm{C}$ was intoxicated with methylmercury chloride $\left(\mathrm{CH}_{3} \mathrm{ClHg}\right)$ at a dose of $5 \mathrm{mgHg} / \mathrm{kg} \mathrm{SFM}$; and group D was fed SFM with an addition of $\mathrm{CH}_{3} \mathrm{ClHg}$ (5mg) and P-dP (3\%). The experiment lasted 8 weeks, but the addition of $\mathrm{CH}_{3} \mathrm{ClHg}$ and P-dP to diets in groups $C$ and $D$ were stopped during two last weeks (7-8 week of the study).

Methylmercury chloride used in the experiment was obtained from Sigma-Aldrich Corporation. It was carefully mixed with SFM by gradually adding it to a roll mixer. P-dP used in the study was obtained from the PHW Tronina Companyand included the following ingredients: humodetrinite, sedge-alder wood peat, bentonite, dolomite, beidellite, feed-grade phosphate, fodderlimestone, plant oil, feed-grade yeasts, and selenium yeast in specified amounts. This preparation, not previously used in layer feeds, is patented in Poland (No. P-209792). Animal handling as well as the experimental procedures were reviewed and accepted by the $2^{\text {nd }}$ Local Ethical Committee of Experimental Procedures on Animals in Wroclaw, Poland.

In order to determine total mercury content of eggs samples, the eggs from each group were collected six times on the following days: 1 day before the beginning of the experiment (series I), day $7 / 8$ (series II), day $14 / 15$ (series III), day 21/22 (series IV), day 41/42 (series V), and day 55/56 (series VI) of the experiment. Six and 12 eggs were collected in series I and series II through V, respectively. In the sixth series of egg collection, only 8-10 eggs from each group were collected because low egg production and high mortality of hens were observed in groups C and D. The scheme of the experiment is presented in Table 1.

The analyses of the total mercury content in studied samples were conducted in the Accredited Research Laboratory of National Marine Fisheries Research Institute in Gdynia (Certificate No. AB 017, certified by the Polish Centre of Testing and Certification). Mercury analysis was conducted using flameless atomic absorption spectrometry on an AMA-254 spectrometer (Altec) with the vapor generation method. Previously homogenized samples were subjected to decomposition in an oxygen atmosphere and elevated temperature. After their release, mercury vapors were concentrated in a catalyst (gold amalgam) and then the concentration was measured using a calibration curve and comparing apparatus indications with a reference material (oyster tissue from National Institute of Standards and Technology, USA). Mercury was analyzed in feed samples, whole eggs, as well as in the albumen, yolk, and eggshells (on fresh weight basis).

Table 1 - Scheme of experiment

\begin{tabular}{|c|c|c|c|c|}
\hline & \multicolumn{4}{|c|}{ Group * } \\
\hline & A & B & C & $\mathrm{D}$ \\
\hline Number of hens & 12 & 12 & 12 & 12 \\
\hline Experimental time (weeks) & 8 & 8 & $6+2 * *$ & $6+2 * *$ \\
\hline Feed and additives & Basal diet (SFM) & $\begin{array}{c}\text { SFM }+3 \% \\
P-d P\end{array}$ & $\mathrm{SFM}+\mathrm{CH}_{3} \mathrm{ClHg}(5 \mathrm{ppm})$ & $\begin{array}{c}\mathrm{SFM}+\mathrm{CH}_{3} \mathrm{ClHg} \\
(5 \mathrm{ppm})+3 \% \mathrm{P}-\mathrm{dP}\end{array}$ \\
\hline \multicolumn{5}{|l|}{ Samples (number of eggs) } \\
\hline Series I & 6 & 6 & 6 & 6 \\
\hline Series II-V & $12 /$ series & $12 /$ series & $12 /$ series & $12 /$ series \\
\hline Series VI & 10 & 10 & 8 & 9 \\
\hline
\end{tabular}

*A - control group; B -addition of 3\% P-dP; C - intoxication with $\mathrm{CH}_{3} \mathrm{ClHg}\left(5 \mathrm{mgHg} / \mathrm{kg}\right.$ SFM); D -intoxication with $\mathrm{CH}_{3} \mathrm{ClHg}(5 \mathrm{mgHg} / \mathrm{kg} \mathrm{SFM})+$ addition of $3 \%$ P-dP.

${ }^{* *}$ No addition of $\mathrm{CH}_{3} \mathrm{ClHg}$ and P-dP for two last weeks (weeks 7-8).

SFM - standard feed mixture.

P-dP - preventive-detox preparation. 
Mean values and standard deviations (SD) were calculated. Duncan's test was performed to evaluate the differences among the groups. All data were analyzed using the IBM SPSS Statistics package (Version 14PL; IBM Corp., Armonk, NY, USA).

\section{RESULTS AND DISCUSSION}

The average content of total $\mathrm{Hg}$ in the SFM without addition of $\mathrm{CH}_{3} \mathrm{ClHg}$ and $\mathrm{P}$-dP was $6.25 \mu \mathrm{g} / \mathrm{kg}$, while in the P-dP it was $0.052 \mathrm{mg} / \mathrm{kg}$. Daily Hg intake was only 0.8 and $1.2 \mu \mathrm{g} / \mathrm{hen}$ in groups $\mathrm{A}$ and $\mathrm{B}$, respectively. This was probably caused by an inorganic form of mercury present in the SFM and in the preparation. Mercury traces of geochemical origin can always be found in fossil fuels, humic materials, feed-grade phosphate, fodderlimestone, and aluminosilicates. The permissible content of $\mathrm{Hg}$ in feeds and feedstuffs (88\% minimum dry matter content) ranges from 0.1 to $0.5 \mathrm{mg} / \mathrm{kg}$ (Regulation of Ministry of Agriculture and Rural Development, 2012). The Hg intake in groups A and $B$ was likely inorganic mercury, which was present only at low levels. Layers in groups $C$ and $D$ received $\mathrm{CH}_{3} \mathrm{ClHg}$ at $5 \mathrm{mg} \mathrm{Hg} / \mathrm{kg}$ of feed, which determined and calculated an average daily intake of 625-700 $\mu \mathrm{g} \mathrm{Hg} /$ hen. According to Fritz (1973), the tolerated mercury dose in poultry feed is $5 \mathrm{ppm}$ and the toxic level is $20 \mathrm{ppm}$. According to another source (Nutrient Requirements, 1994), the toxic concentrations of various mercury compounds in poultry feeds are as follows: 400 ppm for $\mathrm{HgSO}_{4}$ and $\mathrm{HgCl}_{2} ; 33 \mathrm{ppm}$ for $\mathrm{CH}_{3} \mathrm{Hg} ; 3 \mathrm{ppm}$ for $\mathrm{CH}_{3} \mathrm{HgCl}$. At the beginning of the experiment (series I), the mean values of $\mathrm{Hg}$ in the albumen, yolk and eggshell were similar among the groups (Table 2). The maximum value was observed in the eggyolk of group D $(0.0069 \mathrm{mg} / \mathrm{kg})$, while the minimum value $(0.0025 \mathrm{mg} / \mathrm{kg})$ was recorded in eggshell samples of group $C$. The average mercury content in whole eggs ranged from 0.312 to 0.375 $\mu \mathrm{g} \mathrm{Hg} / \mathrm{egg}$, and was not significantly different among the tested groups. The $\mathrm{Hg}$ content in various egg components (albumen, yolk, eggshell) of the treatment groups during six weeks of the experiment (series II-V) is presented in Table 3. Multifold accumulation of $\mathrm{Hg}$ was observed in the groups that were given $\mathrm{CH}_{3} \mathrm{ClHg}$ after only 7-8 days. The mercury content in the whole egg was as much as 488-fold higher in group $C$ and 458-fold in group D compared with the control group (A). The concentration of $\mathrm{Hg}$ in the whole egg of group B was similar to the control. In series III, additional Hg accumulation in eggs of the intoxicated groups ( $\mathrm{C}$ and D) was observed. The mercury content in the whole egg was 622-fold higher in group $C$ and 564-fold higher in group $D$ compared with group $A$. In the next series, some stabilization of the $\mathrm{Hg}$ content in eggs of the intoxicated groups was noted, with a tendency of $\mathrm{Hg}$ level decrease in group $\mathrm{D}$ (intoxication and detoxification). The mercury content in the whole egg was 723-fold higher in group $C$ and 551-fold higher in group $D$ compared with the control one. A slight increase in $\mathrm{Hg}$ concentration in eggs of group $\mathrm{B}$ was observed, but it is still below $1 \mu \mathrm{g} \mathrm{Hg} / \mathrm{egg}$. Finally, no increase in the $\mathrm{Hg}$ content in eggs of the intoxicated groups was observed in series $\mathrm{V}$. Mercury content in the whole egg was 853-fold higher in group $C$ and 646-fold higher in group D compared with the control group. Similar results, with 418 to $755 \mathrm{Hg}$ content, were found in groups $C$ and $D$ compared with group $B$. Comparisons of mean $\mathrm{Hg}$ values in the albumen, yolk and eggshell of all groups are shown in Figures 1-6. Mean mercury content during the period of six weeks of the experiment (series II-V) was 0.374, 0.397, 254.2, $207.5 \mu \mathrm{g} / \mathrm{egg}$ for groups $\mathrm{A}, \mathrm{B}, \mathrm{C}$ and $\mathrm{D}$, respectively. The highest $\mathrm{Hg}$ concentration, recalculated by fresh weight unit $(\mathrm{mg} / \mathrm{kg})$, was accumulated in albumen, yolk and eggshell, respectively.

Table 2 - Mercury content $(\mathrm{mg} / \mathrm{kg})$ in the eggs of laying hens (series I)

\begin{tabular}{|c|c|c|c|c|c|c|c|c|}
\hline \multirow{3}{*}{ Egg component } & \multicolumn{8}{|c|}{ Group * } \\
\hline & \multirow{2}{*}{$\frac{\mathrm{A}}{\text { mean }}$} & \multicolumn{3}{|c|}{ B } & \multicolumn{2}{|c|}{$C$} & \multicolumn{2}{|c|}{ D } \\
\hline & & SD & mean & SD & mean & SD & mean & SD \\
\hline Albumen & 0.0067 & \pm 0.0012 & 0.0052 & \pm 0.0014 & 0.0060 & \pm 0.0013 & 0.0048 & \pm 0.0010 \\
\hline Yolk & 0.0051 & \pm 0.0014 & 0.0045 & \pm 0.0009 & 0.0054 & \pm 0.0021 & 0.0069 & \pm 0.0023 \\
\hline Eggshell & 0.0028 & \pm 0.0006 & 0.0035 & \pm 0.0008 & 0.0025 & \pm 0.0006 & 0.0040 & \pm 0.0011 \\
\hline $\begin{array}{l}\text { Whole egg } \\
(\mu \mathrm{g} / \mathrm{egg})\end{array}$ & 0.375 & \pm 0.052 & 0.312 & \pm 0.045 & 0.351 & \pm 0.039 & 0.343 & \pm 0.048 \\
\hline
\end{tabular}

"A - control group; B -addition of 3\% P-dP; C - intoxication with $\mathrm{CH}_{3} \mathrm{ClHg}\left(5 \mathrm{mgHg} / \mathrm{kg}\right.$ SFM); D -intoxication with $\mathrm{CH}_{3} \mathrm{ClHg}(5 \mathrm{mgHg} / \mathrm{kg} \mathrm{SFM})+$ addition of $3 \%$ P-dP. SD - standard deviation. 
Barej R, Dobrzański Z,

Popiela-Pleban E, Bubel F,

Polak-Juszczak L

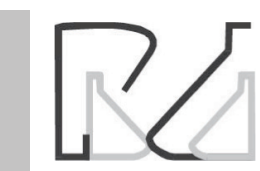

Mercury Bioaccumulation in Eggs of Hens Experimentally Intoxicated with Methylmercury Chloride and Detoxified with a Humic-Aluminosilicate Preparation

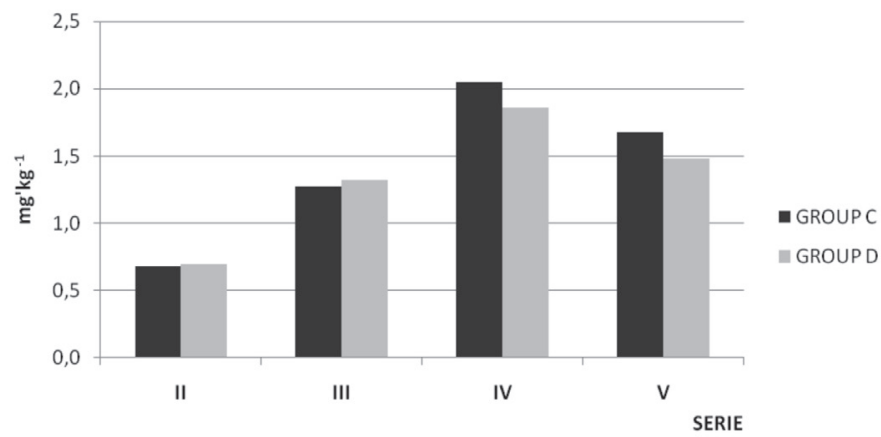

Figure 4 - Mean mercury $(\mathrm{Hg})$ concentration in the egg yolk

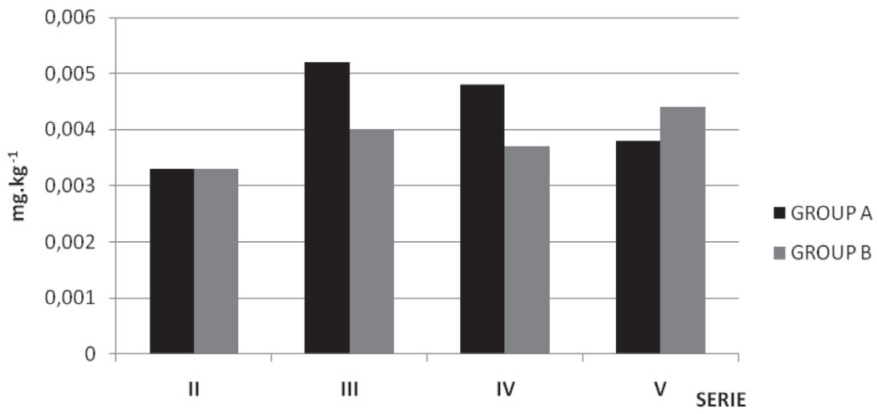

Figure 5 - Mean mercury $(\mathrm{Hg})$ concentration in the eggshell

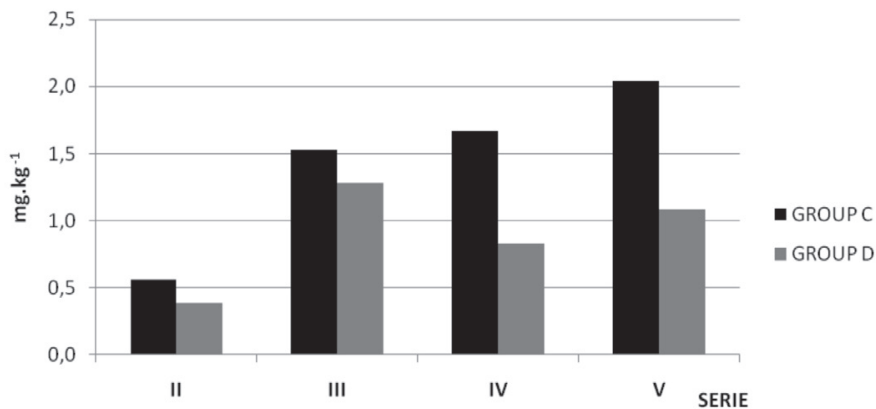

Figure 1 - Mean mercury $(\mathrm{Hg})$ concentration in the egg albumen
SERIE
- GROUPC aROUPD
Figure 3 - Mean mercury $(\mathrm{Hg})$ concentration in the egg yolk

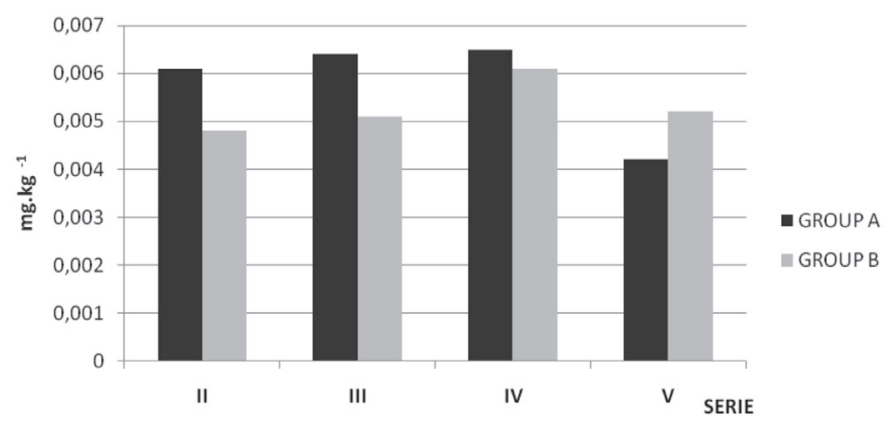

Figure 2 - Mean mercury $(\mathrm{Hg})$ concentration in the egg albumen

Table 3 - Mercury content in whole eggs of the experimental series II,III, IV and V ( $\mu \mathrm{g} / \mathrm{egg})$

\begin{tabular}{|c|c|c|c|c|c|c|c|c|}
\hline \multirow{3}{*}{ Series } & \multicolumn{8}{|c|}{ Group* } \\
\hline & \multicolumn{2}{|c|}{$A$} & \multicolumn{2}{|c|}{ B } & \multicolumn{2}{|c|}{ C } & \multicolumn{2}{|c|}{ D } \\
\hline & mean & SD & mean & SD & mean & SD & mean & SD \\
\hline$\|$ & 0.339 & \pm 0.076 & 0.371 & \pm 0.045 & 165.4 & \pm 34.87 & 155.2 & \pm 31.55 \\
\hline III & 0.453 & \pm 0.065 & 0.397 & \pm 0.056 & 299.7 & \pm 28.50 & 255.6 & \pm 43.55 \\
\hline IV & 0.362 & \pm 0.070 & 0.412 & \pm 0.061 & 261.8 & \pm 30.24 & 199.4 & \pm 23.58 \\
\hline V & 0.340 & \pm 0.047 & 0.406 & \pm 0.092 & 290.0 & \pm 41.33 & 219.7 & \pm 32.94 \\
\hline Mean & $0.374^{\mathrm{A}}$ & \pm 0.054 & $0.397^{A}$ & \pm 0.018 & $254.2^{B}$ & \pm 61.36 & $207.5^{B}$ & \pm 41.89 \\
\hline
\end{tabular}

"A - control group; B -addition of 3\% P-dP; C - intoxication with $\mathrm{CH}_{3} \mathrm{ClHg}(5 \mathrm{mgHg} / \mathrm{kg} \mathrm{SFM}) ; \mathrm{D}$-intoxication with $\mathrm{CH}_{3} \mathrm{ClHg}(5 \mathrm{mgHg} / \mathrm{kg}$ SFM) + addition of $3 \%$ P-dP. Means with different superscript within rows $\left({ }^{A-B}\right)$ differ significantly $(p<0.01)$.

SD - standard deviation. 
Table 4 - Mercury content $\left(\mathrm{mg} / \mathrm{kg}\right.$ ) in the eggs two weeks after the end of $\mathrm{CH}_{3} \mathrm{ClHgandP}$-dP addition (series VI)

\begin{tabular}{|c|c|c|c|c|c|c|c|c|}
\hline \multirow{3}{*}{ Egg component } & \multicolumn{8}{|c|}{ Group* } \\
\hline & \multicolumn{2}{|c|}{ A } & \multicolumn{2}{|c|}{$B$} & \multicolumn{2}{|c|}{$C$} & \multicolumn{2}{|c|}{$D$} \\
\hline & mean & SD & mean & SD & mean & SD & mean & SD \\
\hline Albumen & 0.0061 & \pm 0.0010 & 0.0059 & \pm 0.0012 & 4.75 & \pm 1.23 & 2.92 & \pm 0.34 \\
\hline Yolk & 0.0055 & \pm 0.0011 & 0.0048 & \pm 0.0010 & 1.79 & \pm 0.26 & 1.64 & \pm 0.29 \\
\hline Eggshell & 0.0030 & \pm 0.0004 & 0.0050 & \pm 0.0009 & 1.27 & \pm 0.31 & 0.48 & \pm 0.12 \\
\hline $\begin{array}{l}\text { Whole egg } \\
\text { ( } \mu \mathrm{g} / \mathrm{egg})\end{array}$ & $0.352^{\mathrm{A}}$ & \pm 0.049 & $0.328^{A}$ & \pm 0.051 & $206.6^{B C}$ & \pm 24.7 & $144.8^{B D}$ & \pm 19.6 \\
\hline
\end{tabular}

"A - control group; B -addition of 3\% P-dP; C - intoxication with $\mathrm{CH}_{3} \mathrm{ClHg}\left(5 \mathrm{mgHg} / \mathrm{kg}\right.$ SFM); D -intoxication with $\mathrm{CH}_{3} \mathrm{ClHg}(5 \mathrm{mgHg} / \mathrm{kg}$ SFM) + addition of $3 \%$ P-dP.

Means with different superscript within rows ${ }^{(A-D)}$ differ significantly $(p<0.01)$.

SD - standard deviation.

Two weeks after the end of $\mathrm{CH}_{3} \mathrm{ClHg}$ and P-dP application, interesting changes in egg $\mathrm{Hg}$ concentration were observed (Table 4). Groups A and B presented similar $\mathrm{Hg}$ concentrations in the albumen, yolk, and eggshell, and these were only slightly different from the values obtained in previous analyses (mean $\mathrm{Hg}$ concentrations in egg content was 0.352 and $0.328 \mu \mathrm{g}$, respectively). In the intoxicated group $\mathrm{C}, \mathrm{Hg}$ content in the whole egg was still high $(206.6 \mu \mathrm{g})$, while in group $\mathrm{D}$, that value was $29.9 \%$ lower $(144.8 \mu \mathrm{g})$ relative to group $\mathrm{C}$. The decrease in $\mathrm{Hg}$ concentration ofin the whole egg in groups $C$ and $D$ was determined by a reduction in $\mathrm{Hg}$ content in the albumen. However, no quantitative changes in yolk $\mathrm{Hg}$ content were observed after two weeks. This may be explained by the fact the albumen has higher protein and amino acid content, and therefore, it has higher affinity for methylmercury. The results of this analysis confirm a positive influence of the applied P-dP preparation.

Heinz \& Hoffmann (2004) fed wild ducks with feeds containing 5,10 , or 20 ppm of mercury in the form of methylmercury chloride, and observed an increased $\mathrm{Hg}$ egg content of up to 7, 18, and $35 \mathrm{ppm} \mathrm{Hg}$ of fresh egg weight. Mercury in the form of methylmercury in those eggs was at the level of $95-100 \%$. In the present study, lower $\mathrm{Hg}$ egg levels were observed in the intoxicated groups. Similar $\mathrm{CH}_{3} \mathrm{ClHg}$ intoxication doses were applied for laying hens by Lundholm (1995), who observed physiological disorders, including reduction of egg production on days 4-9 of the experiment and its total egg production inhibition after day 9. Additionally, some of the eggshells of the intoxicated hens were considerably thinner and had a porous surface when compared with the control group. The authors also noted a significant decrease in Ca content in the blood serum, as well as reduced synthesis of prostaglandins in the group treated with methylmercury chloride. Different doses of organic mercury were used by Kambamanoli-Dimau et al. (1991). They applied $500 \mu \mathrm{g} \mathrm{CH}_{3} \mathrm{ClHg} / \mathrm{kg}$ of body weight in group $\mathrm{A}$, and $100 \mu \mathrm{g} \mathrm{CH} \mathrm{CH}_{3} \mathrm{ClHg} / \mathrm{kg}$ in group $B$. The authors did not find any significant differences in birds' activity or egg production between the groups during the course of the experiment. The transfer of methylmercury chloride to the eggs started to increase on the $2^{\text {nd }}$ day of methylmercury chloride application, reaching a maximum concentration in group $A$ on the

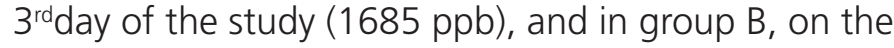
$6^{\text {th }}$ day (1041 ppb). According to the study of Cappon \& Crispin Smith (1981) total Hg content was 5110 $\mathrm{ng} / \mathrm{g}$ in the albumen and $3090 \mathrm{ng} / \mathrm{g}$ in the yolk when the laying hens were given grains contaminated with mercury (13 ppm). The proportion of methylmercury in egg albumen and yolk was $94 \%$ and $16 \%$ of the total Hg content, respectively (Rutkiewicz \& Basau 2013).

After intoxication of hens with phenylmercury chloride, the preparation MESNA (sodium mercaptoethane sulfonate) was found to be useful for the detoxification process (Żarski et al., 2003). Similar properties have been attributed to dimercaprol (BAL) and dimercaptosuccinic acid (DMSA) (Emanuelli et al., 1996; De la Torre et al., 1997). Positive preventivedetox effects may be obtained when using a TOXIPOL adsorptive preparation (Lukashenko \& Khamidullin, 2005) or selenium preparations (Marettova et al., 2003). Selenium lowers mercury bioavailability; however, it may be toxic in excessive amounts (Surai, 2002; Feroci et al., 2005). It was demonstrated in another study (Dobrzański et al., 2003) that mean Hg concentration in duck eggs in areas of industrial contamination was as high as $137.2 \mu \mathrm{g} / \mathrm{kg}$, whereas in typical agricultural/ ecological areas, the concentration was only $39.7 \mu \mathrm{g} /$ $\mathrm{kg}$. In goose eggs, these values were 55.1 and $10.5 \mu \mathrm{g} /$ $\mathrm{kg}$, respectively. The highest amount of $\mathrm{Hg}$ was found 
Barej R, Dobrzański Z, Popiela-Pleban E, Bubel F, Polak-Juszczak L
Mercury Bioaccumulation in Eggs of Hens

Experimentally Intoxicated with Methylmercury

Chloride and Detoxified with a Humic-Aluminosilicate

Preparation in the yolk, and the lowest in the eggshell. On the other hand, Czaban et al. (2013) observed relatively lower mercury concentrations in layer eggs collected in the neighborhood of copper mine tailing ponds.

\section{CONCLUSIONS}

The P-dP preparation at 3\% inclusion level in the diet of laying hens reduced mercury accumulation in the eggs of hens previously intoxicated with methylmercury chloride, but only to a limited magnitude (about 30\%). The single addition of P-dP to a standard feed for layer does not reduce the natural mercury content in the eggs.

\section{REFERENCES}

Barej R, Kwaśnicki R, Chojnacka K, Bolanowski J, Dobrzański Z, Pokorny P. Mercury Content in Rural and Industrial Regions in Lower Silesia. Polish Journal of Environmental Studies 2009;18:547-552.

Barygina VV, Arefeva AS, Zatsepina OV. The role of mercury in the processes of vital activity of the human and mammalian organisms. Russian Journal of General Chemistry 2010;80:2694-2703.

Bykowski PJ, Dobrzański Z. Chemical contamination in fish diet of Polish consumer. Przemysł Chemiczny 2014;93:1763-1766.

Cappon CJ, Crispin SJ. Chemical form and distribution of mercury and selenium in eggs from chickens fed mercurycontaminated grain. Bulletin of Environmental Contamination and Toxicology 1981;26:472478.

Chojnacka K, Chojnacki A, Górecka H, Górecki H. Bioavailability of heavy metals from polluted soils to plants. Science of the Total Environment 2005;337:175-182.

Clarkson TW, Magos L. The toxicology of mercury and its chemical compounds. Critical Reviews in Toxicology 2006;36:609-662.

Czaban S, Kołacz R, Dobrzański Z, Bubel F, Opaliński S, Durkalec M, et al. Mercury content in the area of the "Żelazny Most" tailings pond. Przemysł Chemiczny 2013; 92:1268-1271.

De La Torre A, Belles M, Llobet JM, Mayayo E, Domingo JL. Comparison of the effectiveness of 2,3 - dimercaptopropanol (BAL) and meso-2,3dimercaptosuccinic acid (DMSA) as protective agents against mercuric chloride - inducted nephrotoxicity in rats. Biological Trace Element Research 1998;63(1):1-10.

Dobrzański Z, Chojnacka K, Górecka H, Chojnacki A, Wiśniewski J. Chemical content of waterfowl eggs from industrial and agricultural regions. Chemistry for Agriculture 2003;4:524-529.

Dobrzański Z, Korniewicz D, Kołacz R, Górecka H, Trziszka T, Chojnacka K, et al. Organic-mineral preparation limiting the accumulation of heavy metals in animals, especially poultry. Poland Patent 209792, 2010 Nov 19.
Emanuelli T, Rocha JBT, Pereira ME, Porciuncula LO, Morsch VM, Martins AF, et al. Effect of Mercuric chloride intoxication and dimercaprol treatment on $\sigma$ - aminolevulinate dehydrates from brain, liver and kidney of adult mice. Pharmacology \& Toxicology 1996;79(3):136-143.

Feroci $G$, Bandello $R$, Fine $A$. Interactions between different selenium compounds and zinc, cadmium and mercury. Journal of Trace Elements in Medicine and Biology 2005;18:227-234.

Fritz J. Trace elements. Needs and tolerances. Proceedings of the Maryland Nutrition Conference for Feed Manufactures; 1973; College Park, USA; 1973. p. 49.

Heinz GH, Hoffmann DJ. Mercury accumulation and loss in mallard eggs. Environmental Toxicology and Chemistry 2004;23(1):222-224.

Kambamanoli-Dimou A, Kamarianos A, Kilikidis S. Transfer of methylmercury to hens' eggs after oral administration. Bulletin of Environmental Contamination and Toxicology 1991;46:128-133.

Lukashenko VS, Khamidullin TN. Production of environment safe broiler meat. Proceedings of the 17th European Symposium on the Quality of Poultry Meat; 2005; Doorwerth, The Netherlands; 2005. p.367.

Lundholm CE. Effects of methylmercury at different dose regimes on eggshell formation and some biochemical characteristics of the eggshell gland mucosa of the domestic fowl. Comparative Biochemistry and Physiology 1995;110C(1):23-28.

Marettova E, Maretta M, Legat J, Nad P. The effect of selenium on phenyl mercury toxicity and mercury retention in chicken. Acta Veterinaria (Beograd) 2003;53:211-218.

NRC - Nutrient requirements of poultry. 9thed. Washington: National Academy Press; 1994.

Regulation of Ministry of Agriculture and Rural Development from 6 Feb. 2012 Journal of Laws 2012; no. 37 pos.203 (in Polish).

Rutkiewicz J, Basau N. Methylmercury egg injections: Part 1-Tissue distribution of mercury in the avian embryo and hatchling. Ecotoxicology and Environmental Safety 2013; 93: 68-76.

Surai PF. Selenium in poultry nutrition. World's Poultry Science Journal 2002:58:333-349

Van Overmeire I, PussemierL, Hanot V, De Temmerman L, HoenigM, Goeyens L. Chemical contamination of free-range eggs from Belgium. Food Additives and Contaminants 2006;23:109-112.

Virtanen JK, Rissanen TH, Voutilainen S, Tuomainen TP. Mercury as a risk factor for cardiovascular diseases. The Journal of Nutritional Biochemistry 2007;18:75-85.

Zahir F, Rizwi SJ, Haq SK, Khan RH. Low dose mercury toxicity and human health. Environmental Toxicology and Pharmacology 2005;20(2):351360.

Żarski TP, Arkuszewska E, Samek M, Majdecka T. The evaluation of detoxicating properies of the sodium salt of 2-mercaptoethanolsulphonic acid (Mesna) in experimental mercury poisoning in chicken. EJPAU series Animal Husbbandry 2003;6(2):6. 